\title{
VALIDATION OF SRTM X BAND DEM OVER HIMALAYAN MOUNTAIN
}

\author{
R.D. Gupta ${ }^{1}$, Mritunjay Kumar Singh ${ }^{1,2}$, Snehmani $^{2}$, A. Ganju ${ }^{2}$ \\ ${ }^{1}$ Motilal Nehru National Institute of Technology Allahabad, Allahabad- 211004, India (gupta.rdg@gmail.com) \\ ${ }^{2}$ Snow \& Avalanche Study Establishment-Research and Development Center (SASE-RDC), Him Parisar, Plot No. 1, Sector 37A, \\ Chandigarh-160036, India (jay_rsgis@yahoo.co.in; snehmani@gmail.com; ashwagosha@gmail.com) \\ *Corresponding author (e-mail:gupta.rdg@gmail.com, Phone: +91-9838346268)
}

KEY WORDS: SRTM X, ADS80, DEM, Himalaya, Accuracy

\begin{abstract}
The present research study assesses the accuracy of the SRTM X band DEM with respect to high accuracy photogrammetric Digital Elevation Model (DEM) for parts of the Himalaya. The high resolution DEM was generated for Manali and nearby areas using digital aerial photogrammetric survey data of $40 \mathrm{~cm}$ Ground Sampling Distance (GSD) captured through airborne ADS80 pushbroom camera for the first time in Indian Himalayan context. This high resolution DEM was evaluated with Differential Global Positioning System (DGPS) points for accuracy assessment. The ADS80-DEM gave root mean square error (RMSE) of $\sim<1 \mathrm{~m}$ and linear error of $1.60 \mathrm{~m}$ at $90 \%$ confidence (LE 90) when compared with the DGPS points. The overall RMSE in vertical accuracy was $73.36 \mathrm{~m}$ while LE 90 was $75.20 \mathrm{~m}$ with regard to ADS80 DEM. It is observed that the accuracy achieved for part of Himalayan region is far less as compared to the values officially claimed. Thus, SRTM X band DEM should be used with due care in mountainous regions of Himalaya.
\end{abstract}

\section{INTRODUCTION}

A Digital Elevation Model (DEM) is a three Dimensional (3D) representation of a terrain surface using two Dimensional (2D) raster file containing terrain height (elevation) as pixel value at regularly spaced horizontal intervals (Snehmani et al. 2013). It is a quantitative representation of earth's surface providing basic information about the terrain relief. DEM and its resulting parameters are the fundamental terrain related information (Guth, 2006). DEM and the extracted information (slope, aspect, roughness etc.) have been recognized as one of the most important and fundamental variables to various streams of geoscientific research. Zaher et al. (2013) delineated the major surface and subsurface structures to evaluate tectonic framework for South Western desert of Egypt using Shuttle Radar Topographic Mission (SRTM) DEM data.

DEM can be generated using different techniques including ground surveying techniques (e.g. DGPS, GPS, Total Station, Leveling. etc.), aerial photogrammetric technique (close range and far range stereo aerial photograph), existing topographic map derived products (e.g. spot heights, contours), airborne Lidar-grammetric technique (Lidar point cloud), satellite and airborne Interferometry technique data (Insar/Ifsar), radargrammetric technique (e.g. RadarSat, Envisat/Asar and TeraSAR-X), and Optical satellite sensor data (e.g. World View-1, Quick bird, IKONOS, ASTER, Cartosat-1, ALOSPrism). The most accurate DEMs within these techniques/methods are the once extracted from ground surveying data (Kayadibi, 2009). However, the limitation of using DEM derived using ground survey data is that it is more expensive, time consuming and involves much more effort as compared to other methods.

It is important to focus on the accuracy of the DEM data as this can influence the accuracy and effectiveness of study and modelling of geo-processes. These errors are more prominent in high mountainous terrain. The accuracy of DEM products should be tested and specified prior to any type of geoscientific, climatological and environmental modelling.
Unfortunately, most of the end users of DEMs are unaware about the quality of this height data and their impact on the derived products. The accuracy of the DEM is governed by on numerous elements such as the source data and method of computing height data, the dispersal and compactness of the sampled point data, the interpolation technique used for DEM generation, precision of height data along with the terrain difficulty of landscape, etc. (Theobald, 1989). Apart from this, importance of DEM in various applications is thoroughly described by Sulebak (2000). Further, DEMs can be produced at different spatial scales according to requirement of a particular application by adopting its own cost effective technique (Hutchinson and Gallant 2000).

The main aim of the present work is to assess freely available SRTM X band DEM with respect to high resolution $(1 \mathrm{~m})$ aerial photogrammetric DEM for parts of Himalayan mountain. High resolution DEM was generated for Manali and nearby areas using digital aerial photogrammetric survey data of $40 \mathrm{~cm}$ Ground Sampling Distance (GSD) captured through airborne ADS80 push-broom camera for the first time in Indian Himalayan context. The ADS80-DEM is having high vertical accuracy of $1.60 \mathrm{~m}$ linear error at 90\% (LE 90) (Singh et al., Under Review). The overall RMSE in vertical accuracy was $73.36 \mathrm{~m}$ while LE90 was $75.20 \mathrm{~m}$ for SRTM-X band DEM when compared with ADS80 DEM.

\section{RELATED WORKS}

Koch et al. (2002) observed maximum height difference between of about $450 \mathrm{~m}$ for a test site in south of Hannover, Germany, when comparing SRTM X-band DEM with trigonometric points and the high accuracy reference DTM. In a recent study Kolecka \& Kozak, (2013) observed RMSE of 38.47 m vertical accuracy of SRTM X-band DEMs for Polish Tatra Mountains with respect to photogrammetric DEM. They concluded that slope, local incidence angle, aspect and radar beam geometry are the most important factors that affect the accuracy of the $\mathrm{X}$ - band DEM. 


\section{STUDY AREA AND DATA USED}

The area of study (Figure 1) is about $500 \mathrm{~km}^{2}$ in Himalayan mountainous region covering Dhundi, Solang, Manali sites of Himachal Pradesh, India. In winter area receives heavy to moderate snowfall. Study area is the part of NW-Himalaya, which is high mountainous area having the mean altitude of 4431 meters, comprises of highly rugged hills and mountains with very narrow valleys, deep gorges having very high gradient. In the study, area there is sharp variation in slopes approaching up to $83^{\circ}$. The study area comprises avalanche prone terrain from Manali to Rohtang (HP) which is the part of important Manali- Leh highway.

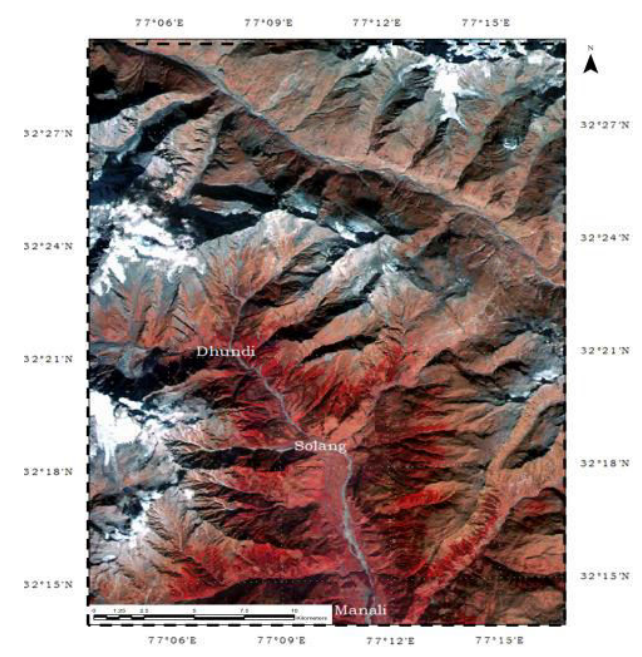

Figure 1: Multispectral Image showing the Study Area

\section{ADS80 DEM}

The ADS80 High spatial resolution (1m spatial resolution) DEM (Figure 2) has been obtained from the SASE (Snow and Avalanche Study Establishment) Archive Database for this study. The high resolution DEM had been generated from ADS80 stereo images at 40cm GSD.

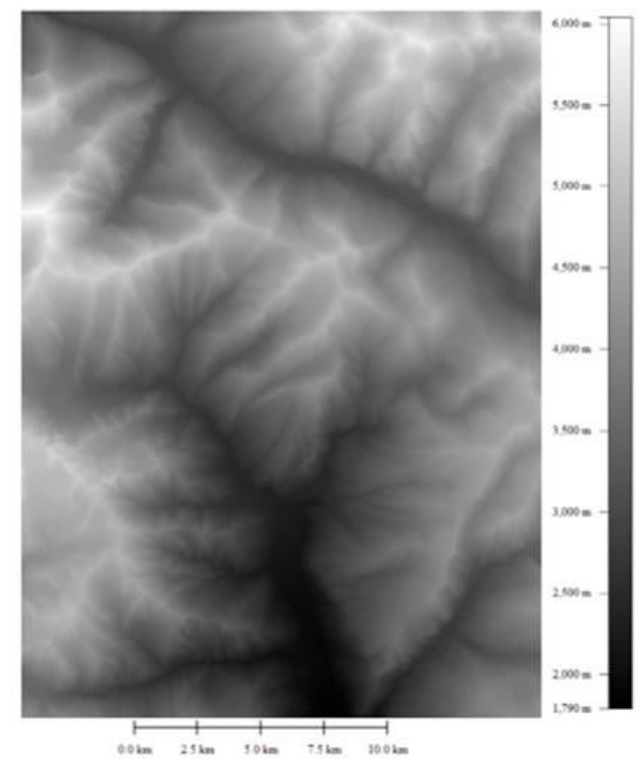

Figure 2: ADS80 High Spatial Resolution (1m Spatial Resolution) DEM
ADS80 was configured for providing stereo panchromatic data from three stereo angles, $14^{\circ}$ backward, $2^{\circ}$ forward and $27^{\circ}$ forward (Gehrke et al. 2011). But largest viewing angle $\left(27^{\circ}\right.$ forward) combination was avoided for stereo photogrammetric purpose in order to minimise distortion. The ADS80 data acquisition in the study area had occurred between $30-31^{\circ}$ sun elevation angles on a flying altitude of $25,25,500 \mathrm{ft}$ above mean sea level with North to South flight line. The full swath width of the acquired ADS80 image strip is $4,800 \mathrm{~m}$ with $40 \%$ side-lap. The generated DEM is having $1.36 \mathrm{~m}$, linear error at $90 \%$ confidence interval (LE90) (Singh et al., Under Review).

The ADS80 DEM is of high accuracy and can be used for accurate modelling in different applications such as glacier mass balance studies and avalanche hazard mapping as well as for comparison of accuracy of other available DEMs.

\section{SRTM X-SAR DEM}

The SRTM mission has been the first mission using space-borne single-pass Interferometric SAR (Synthetic Aperture Radar) instrument to produce a near-global digital elevation map of the earth's land surface with nominal absolute horizontal and vertical accuracies are $\pm 30 \mathrm{~m}$ and $\pm 16 \mathrm{~m}$ respectively (Nikolakopoulos et al., 2006). SRTM 3-arc-second product (90m resolution) is freely available for the entire world and can be downloaded freely from USGS website. The data is provided in WGS-84 geoid model and converted ellipsoid model using EGM 2008 geoid model.

The SRTM X-SAR DEMs were generated from X-band synthetic aperture radar (SAR) data acquired during the SRTM operations conducted jointly between the German Aerospace Centre (DLR), the Italian Space Agency (ASI) and NASA/JPL (USA) in 2000 (Czubski et al., 2013). The DLR is making the SRTM X-SAR DEMs available at no cost. The DLR/ASI XSAR DEMs cover the entire globe between $60^{\circ}$ northern and southern latitudes.

The pre-mission accuracies reported is $\pm 16 \mathrm{~m}$ absolute vertical (AV) and $\pm 6 \mathrm{~m}$ relative vertical (RV) for 90 percent of the data (Weydahl et al., 2007). Figure 3 represents SRTM X band DEM of the study area.

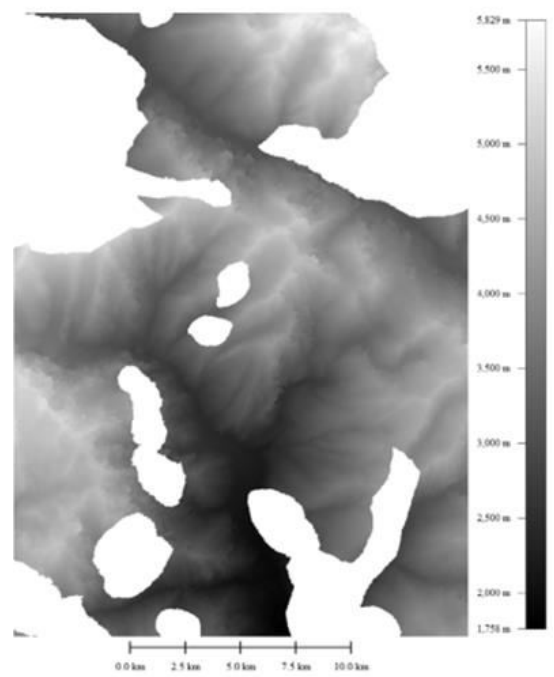

Figure 3: SRTM X band DEM of the Study Area 


\section{METHODOLOGY}

For nullifying the impact of miss-registration on the computed error (difference DEM) $\mathrm{X}$ band DEM was reprojected to the projection system as that of the reference high resolution ADS80 DEM, i.e., UTM with datum being WGS84. For making the analysis fare enough, the high resolution DEM was downsampled to $30 \mathrm{~m}$ spatial resolution as well as the $\mathrm{X}$ band DEM was also resampled to $30 \mathrm{~m}$.

SRTM-X band DEM was co-registered with reference to the ADS80 DEM by assuming ADS80 high resolution DEM as master image. As $\mathrm{X}$ band DEM and reference DEM are having the same Datum (WGS84), so there was no need of applying any type of datum transformation. Table 1 presents the error statistics for co-registration. Figure 4 shows the histogram of the ADS80 DEM while Figure 5 shows the histogram of SRTM $\mathrm{X}$ band DEM.

Table 1: Error Statistics for Co-Registration

\begin{tabular}{|c|c|c|l|l|}
\hline $\begin{array}{l}\text { S. } \\
\text { No. }\end{array}$ & $\begin{array}{l}\text { Data } \\
\text { Type }\end{array}$ & $\begin{array}{l}\text { Observed } \\
\text { RMSE in X } \\
\text { direction } \\
\text { after Co- } \\
\text { registration } \\
\text { in ground } \\
\text { units (m) }\end{array}$ & $\begin{array}{l}\text { Observed } \\
\text { RMSE in Y } \\
\text { direction } \\
\text { after Co- } \\
\text { registration } \\
\text { in ground } \\
\text { units (m) }\end{array}$ & $\begin{array}{l}\text { Observed } \\
\text { RMSE } \\
(\mathbf{m})\end{array}$ \\
\hline 1. & $\begin{array}{c}\text { ADS80 } \\
\text { DEM }\end{array}$ & $\begin{array}{c}\text { Master } \\
\text { DEM }\end{array}$ & - & - \\
\hline 2. & $\begin{array}{c}\text { SRTM } \\
\text { X Band } \\
\text { DEM }\end{array}$ & 6.90 & 4.34 & 8.15 \\
\hline
\end{tabular}

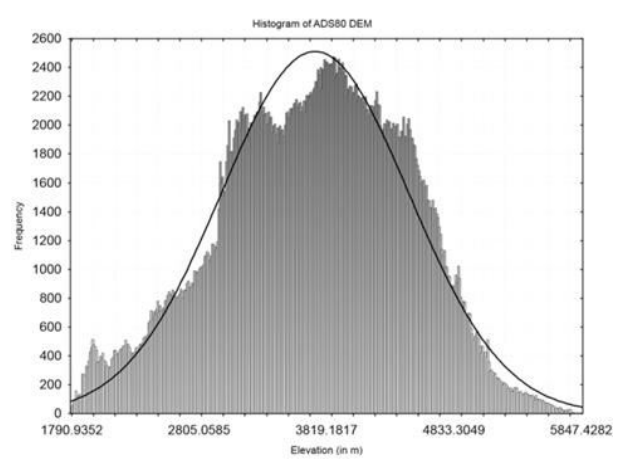

Figure 4: Histogram of ADS80 DEM

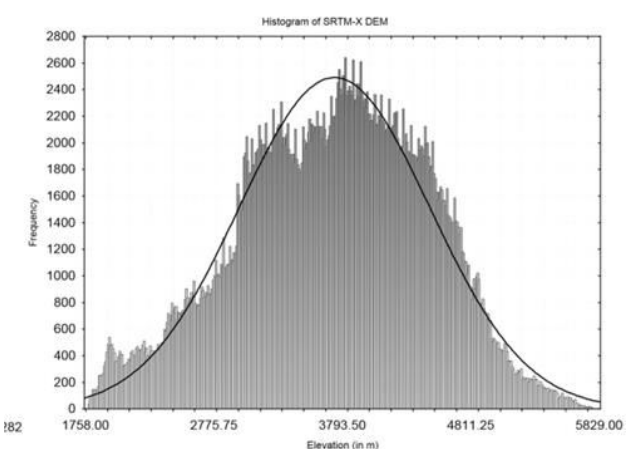

Before generating the error (difference) DEM, the areas having voids in the $\mathrm{X}$ band DEM were masked out and the same masks were applied to reference DEM also for fair comparison. The difference images (Figure 6) for statistical analyses was generated by subtracting SRTM-X band DEM from reference ADS80 DEM. Figure 7 shows the histogram of the error (difference) DEM.

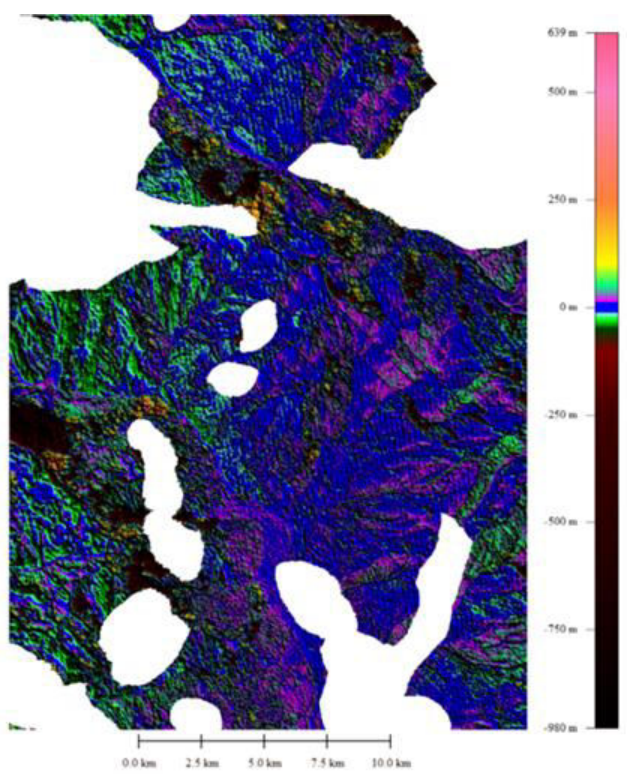

Figure 6: Difference images (ADS80-SRTM X band DEM)

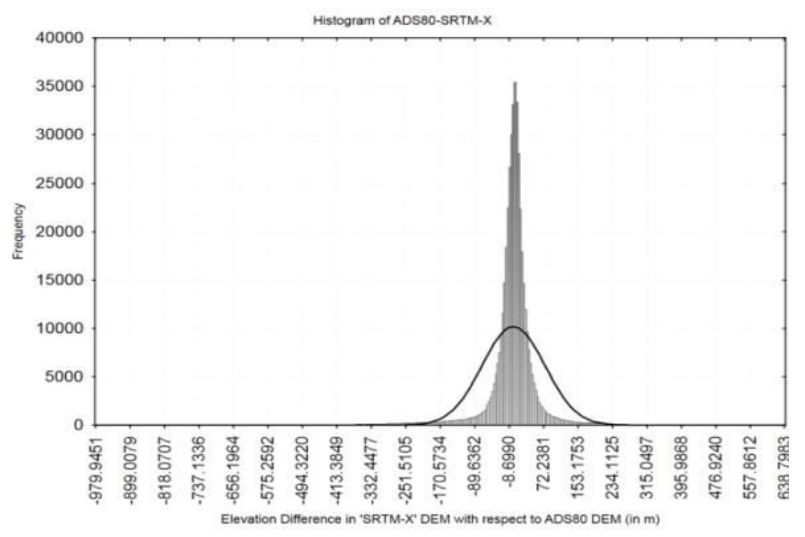

Figure 7: Histogram of the Error (Difference) DEM

\section{DISCUSSIONS OF RESULTS AND CONCLUSIONS}

Table 2 present the statistics related with the DEMs used for the study after masking voids and resampling to $30 \mathrm{~m}$. Minimum and maximum elevations of ADS80 DEM were $1790.9 \mathrm{~m}$ and $5847 \mathrm{~m}$ respectively while SRTM X band SEM is showing underestimate with minimum and maximum observed value of $1758.0 \mathrm{~m}$ and $5829 \mathrm{~m}$.

Table 3 represents the statistical summary of difference/ error DEM. The error shows overestimate in the mean by giving value of $-3.29 \mathrm{~m}$.

Figure 5: Histogram of SRTM X band DEM) 
Table 2: Statistics related with the used DEMs

\begin{tabular}{|c|c|c|c|c|c|}
\hline $\begin{array}{c}\text { DEM } \\
\text { Used }\end{array}$ & $\mathbf{N}^{*}$ & $\begin{array}{c}\text { Mean } \\
(\mathbf{m})\end{array}$ & $\begin{array}{c}\text { Min } \\
(\mathbf{m})\end{array}$ & $\begin{array}{c}\text { Max } \\
(\mathbf{m})\end{array}$ & $\begin{array}{c}\text { Std. } \\
\mathbf{D e v} . \\
(\mathbf{m})\end{array}$ \\
\hline ADS80 & 462364 & 3717.7 & 1790.9 & 5847.0 & 745.03 \\
\hline $\begin{array}{c}\text { SRTM-X } \\
\text { DEM }\end{array}$ & 462364 & 3721.0 & 1758.0 & 5829.0 & 753.63 \\
\hline
\end{tabular}

Table 3: Statistical Summary of Difference/ Error DEM

\begin{tabular}{|c|c|c|c|c|c|c|c|}
\hline $\begin{array}{c}\text { ADS8 } \\
\text { DEM }\end{array}$ & N & $\begin{array}{c}\text { Mean } \\
(\mathbf{m})\end{array}$ & Min (m) & $\begin{array}{c}\text { Max } \\
(\mathbf{m})\end{array}$ & $\begin{array}{c}\text { Std. } \\
\text { Dev. } \\
(\mathbf{m})\end{array}$ & $\begin{array}{c}\text { RMSE } \\
(\mathbf{m})\end{array}$ & $\begin{array}{c}\text { LE90 } \\
(\mathbf{m})\end{array}$ \\
\hline $\begin{array}{c}\text { SRTM-X } \\
\text { DEM }\end{array}$ & 462364 & -3.29 & -979.95 & 639 & 73.29 & 73.36 & 75.20 \\
\hline
\end{tabular}

Accuracy is normally presented using RMSE (Root Mean Square Error) value but more robust measure of DEM accuracy is linear error at $90 \%$ confidence interval. In the present study, SRTM X band DEM shows RMSE of $73.36 \mathrm{~m}$ with respect to ADS80 DEM which is quite high from the clamed ones. The calculated LE 90 is $75.20 \mathrm{~m}$.

It can be observed from the above comparison of SRTM X band DEM with ADS80 reference DEM that the accuracy achieved for part of Himalayan region is far less as compared to the values officially claimed. Thus, SRTM X band DEM should be used with due care in mountainous regions of Himalaya.

\section{REFERENCES}

1. Czubski, K., Kozak, J. and Kolecka, N., 2013. Accuracy of SRTM-X and ASTER Elevation Data and its Influence on Topographical and Hydrological Modelling: Case Study of the Pieniny Mts. in Poland. International Journal of Geoinformatics, 9(2), 7-14.

2. Gehrke, S., Uebbing, R., Downey, M., Morin, K., 2011. Creating and using Very High Density Point Clouds derived from ADS imagery. In: Proc of the ASPRS Annual Conference, Milwaukee, Wisconsin.

3. Guth, P.L., 2006. Geomorphometry from SRTMComparison to NED. Photogrammetric Engineering \& Remote Sensing 72 (3), 269-277.

4. Hutchinson, M.F. and Gallant, J.C., 2000. Digital Elevation Models and Representation of Terrain Shape, In: Wilson GJC et al. (ed.) Terrain Analysis; Principles and Applications, John Wiley and Sons, NY: 29-50.

5. Kayadibi, O., 2009. Recent Advances in Satellite Technologies used to generate the Digital Elevation Model (DEM). $4^{\text {th }}$ International Conference on Recent Advances in Space Technologies. 2009. 380-385p.

6. Koch, A., Heipke, C., Lohmann, P., 2002. Analysis of SRTM DTM methodology and practical results. Symposium on Geospatial Theory, Processing and Applications. Commission IV, WG IV/6, pp. 1-6. Ottawa: ISPRS.
7. Kolecka, N., Kozak, J., 2013. Assessment of the Accuracy of SRTM C- and X-Band High Mountain Elevation Data: a Case Study of the Polish Tatra Mountains. Pure and Applied Geophysics, DOI 10.1007/s00024-013-0695-5.

8. Nikolakopoulos, K.G., and Nektarios, C., 2006. Updating the 1:50.000 Topographic Maps using ASTER and SRTM DEM. The case of Athens, Greece. Proc. of SPIE. 2006. 6366, 6366061-11.

9. Singh, M.K., Snehmani, Gupta, R.D., Bhardwaj, A., Joshi, P.K. and Ganju, A., 2014. High Resolution DEM Generation for Complex Snow Covered Indian Himalayan Region Using ADS80 Aerial Push-broom Camera: A First Time Attempt. Arabian Journal of Geosciences. DOI: 10.1007/s12517-014-1299-9.

10. Snehmani, Singh M.K., Gupta R.D., Ganju A., 2013. Extraction of High Resolution DEM from Cartosat-1 Stereo Imagery using Rational Math Model and its Accuracy Assessment for a part of Snow covered NWHimalaya. J of Remote Sens and GIS (JORSG) 4 (2): 2334.

11. Sulebak, J.R., 2000. Applications of Digital Elevation Models. DYNAMAP Proj Oslo.

12. Theobald, D.M., 1989. Accuracy and Bias Issues in Surface Representation. In: Goodchild, M., Gopol, S. (Eds), Accuracy of Spatial Databases. Taylor and Francis, Bristol, PA, 99-106.

13. Weydahl, D.J., Sagstuen, J., Dick, Ø.B. and Rønning, H., 2007. SRTM DEM Accuracy Assessment over Vegetated Areas in Norway. International Journal of Remote Sensing, 28(16), 3513-3527.

14. Zaher, M.A., Saadi, N.M., Watanabeb, K., 2013. Geological Application Potential of DEM, ETM+, and Gravity Data in Arid and Semi-Arid Regions with Special Reference to South Western Desert, Egypt. Arabian Journal of Geoscience. doi: 10.1007/s12517-013-0847-z. 